\title{
Konsep Kurikulum dan Metode Pendidikan Anak dan Remaja Perspektif Ibnu Khaldun
}

\author{
Ahmad Falah \\ ST AIN Kudus, Jawa Tengah, Indonesia \\ ahmadfalah97@gmail.com
}

\begin{abstract}
Abstrak
Tujuan penelitian adalah untuk mendeskripsikan konsep kurikulum dan metode pendidikan anak dan remaja menurut Ibnu Khaldun. Metode yang digunakan dalam penelitian ini lebih bersifat penelitian kepustakaan (library research) dengan membaca karya-karya Ibnu Khaldun sebagai data primer yaitu kitab Muqaddimah Ibnu Khaldun dan kitab-kitab pendukung lainya. Kajian ini menghasilkan bahwa kurikulum dan metode pendidikan anak dan remaja menurut Ibnu Khaldun kembali pada prinsip epistemologi yang dibangun yaitu Al Qur'an dan Al Hadist sebagai sumber primernya. Mengajarkan al-Qur'an Hadist pada anak perlu untuk didahulukan untuk menanamkan keimanan anak yang baik dan benar. Pada aspek kurikulum pendidikan anak secara keseluruhan sebagai berikut: a. al-Qur'an, b. alHadits, c. Bahasa Arab, d. Syi'ir (sastra), e. Kisah-kisah yang baik atau sejarah, f. Akhlak / budi pekerti, g. Ilmu hitung.
\end{abstract}

Kata Kunci: Kurikulum, Metode, Pendidikan, Anak, Ibnu Khaldun

\begin{abstract}
The purpose of the study is to describe the curriculum concept and education method of children and adolescents according to Ibn Khaldun. The method used in this study is a library research by reading the works of Ibn Khaldun as primary data, namely the book of Muqaddimah Ibn Khaldun and other supporting books. This study resulted in the curriculum and education methods of children and adolescents according to Ibn Khaldun back to the epistemological principle that was built, namely the Qur'an and Al Hadist as the primary source. Teaching the Qur'an and Hadith to children needs to take precedence to instill good and true children's faith. The whole aspect of the child's education curriculum as follows: a. the
\end{abstract}


Qur'an, b. al-Hadith, c. Arabic, d. Syi'ir (literature), e. Good stories or history, f. Morals/manners, g. Arithmetic.

Keywords: Curriculum, Methods, Education, Children, Ibn Khaldun

\section{A. Pendahuluan}

Pendidikan merupakan salah satu penopang sebuah negara, ia memiliki peranan penting dalam upaya pencapaian kemajuan bangsa. Pendidikan merupakan salah satu fenomena sosial yang sangat mempengaruhi pertumbuhan dan perkembangan individu dan masyarakat yang melibatkan orang tua, pendidikan dan lingkungan.

Sebagian dari masyarakat adalah remaja sebagai individu yang pada prinsipnya memiliki akal yang sehat yang dapat dan harus dimanfaatkan untuk mencari ilmu pengetahuan. Potensi tersebut memberi kemungkinan kepada remaja untuk mengembangkan kepribadiannya. Pengembangan akal pikiran yang sehat dilatarbelakangi oleh kesadaran berfikir yang dimiliki oleh remaja (Abdullah,1900:VII).

Dalam perkembangan kepribadian, akal fikiran dan potensi anak yang melalui fase-fase perkembangan tertentu, anak memerlukan bimbingan, pengajaran, pengendalian dan kontrol dari orang tua dan pendidik. Remaja yang merupakan dasar awal dari pembentukan menjadi dewasa harus diperhatikan dengan sungguh perkembangannya oleh orang tua dan pendidik. Hal ini dengan tujuan mempersiapkan perkembangan anak agar mampu berperan serta secara berkesinambungan dalam pembangunan manusia yang berkembang terus dan mampu beramal kebajikan dalam arti berakhlak mulia selama dalam upaya mencari kebahagiaan di dunia dan akhiratnya (Ali al Jumbulati, 1994: 5).

Remaja tidak dapat tumbuh dan berkembang serta menerima ilmu pengetahuan begitu saja, tetapi harus dengan pengajaran dan bimbingan dari orang tua dan pendidik. Orang tua dan pendidiklah dan didukung oleh lingkungan baik yang berperan dalam mengembangkan bakat dan minat anak, karena faktor yang dari dalam yaitu faktor keturunan tidak banyak pengaruhnya pada diri anak. Hal ini dapat dikatakan bahwa anak secara fitri (alami) bersih 


\section{Konsep Kurikulum dan Metode Pendidikan Anak dan Remaja ...}

dari warna tertentu dan mirip dengan teori tabula atau lembaran putih yang dikemukakan oleh tokoh pendidikan Barat yaitu Jhon Lock. Sedangkan proses belajar serta mendapatkan ilmu pengetahuan sama dengan proses menulis dan membuat garis di atas lembaran putih tersebut (Fathiyah, 1991: 92).

Dari sinilah dapat ditarik pengertian bahwa peranan dan tanggung jawab orang tua selaku pendidik utama dan pertama dan pendidik dalam arti guru sangat besar dalam mengantarkan anak ke jenjang pendidikan yang lebih baik dan membentuk anak agar tumbuh dan berkembang dengan baik dan sempurna hingga dewasa.

Perkembangan dunia pendidikan tentunya tidak akan terlepas dari sumbangsih para ilmuwan yang mencurahkan segala perhatiannya pada dunia pendidikan ini. Begitu pun yang dilakukan oleh para ulama sebagai yang merasa berkewajiban untuk menyebarluaskan ilmu. Salah satu ulama besar, filosof, psikolog dan sosiolog sekaligus intelektual muslim yakni Ibnu Khaldun. Maka dari sinilah dirasa perlu menampilkan konsep dan pemikiran beliau tentang pendidikan remaja yang menyoroti mengenai peran, tugas dan tanggung jawab pendidik terhadap anak dalam proses belajar mengajar atau interaksi edukatif. Beliau mengatakan "tidak cukup seorang pendidik hanya membekali anak dengan ilmu pengetahuan saja agar mereka menjadi orang yang berilmu pengetahuan menambah kemampuannya dalam belajar Akan tetapi juga pendidik wajib memperbaiki metoda dalam penyajian ilmu kepada anak didiknya; dan hal itu tidak akan sempurna kecuali dengan lebih dahulu mempelajari hidup kwajiban anak dan mengetahui tingkattingkat kematangannya serta bakat-bakat ilmiahnya, sehingga ia mampu menerapkan sesuai dengan tingkat pikiran mereka" (Ali al Jumbulati, 1994: 195-196).

Dengan adanya hal seperti itu merupakan sesuatu yang melatarbelakangi mengadakan penelitian ini, disamping karena adanya keinginan mengkaji hasil konsep dan pemikiran salah seorang tokoh terdahulu yang sangat terkemuka dengan kitabnya yang bejudul Muqaddimah. Mengingat sebagian para pelajar dan akademika yang lebih condong kepada karya pemikir Barat dan lebih tertarik dengan pendidikan sekuler, sehingga mereka sering terjebak dan termakan oleh teori dan praktek pendidikan Barat, 
namun hal ini bukanlah berarti harus dihindari atau ditolak, tetapi hendaknya ilmu pengetahuan itu diambil dan dipelajari dengan membuang yang tidak baik dan menambah yang kurang selama hal itu bermanfaat dan tak lupa selalu berpegang kepada al-Qur'an, asSunnah dan ijtihad yang istilah sekarang dengan lewat islamisasi ilmu pengetahuan.

Sosok figur Ibnu Khaldun sebagai sarjana dan ulama besar, kebanggaan umat Islam dan pencipta ilmu sosial benar-benar merupakan pujaan dan bintang kejora (Nashruddin, 1979: 58). Ibnu Khaldun sebagai ulama dan sarjana besar menurut etimologi dan semantiknya, keahliannya dan ilmunya tidak tanggung-tanggung di seluruh bidang ilmu-ilmu naqliyah yang mencakup ilmu-ilmu agama dan ilmu alat dan ilmu-ilmu aqliyah yang meliputi ilmu-ilmu umum.

Beliau tidak hanya seorang sosiolog, beliau juga seorang sejarawan dan tokoh pemikir pendidikan, hal ini ditinjau pada pendidikan anak-anak. Pengalamannya sebagai mahaguru di Universitas al-Azhar yang dibangun oleh khalifah al-Muiz dari dinasti Fatimiyah yang ada di Kairo Mesir dan guru besar di universitas Sragtmus. Selama 20 tahun lebih beliau memberikan kuliah dan tentunya beliau mempunyai wawasan yang luas, pemikiran yang mendalam sehingga patut dikaji dan diteliti.

Umat Islam yang pada umumnya menyakini akan kealiman dan kemasyhuran Ibnu Khaldun yang mana N.J. Dawood menyebutnya sebagai negarawan, ahli hokum, sejarawan dan sarjana (Ahmad, 1996: 11), maka ironisnya sekali apabila tidak mengenal terhadap mutiara konsep dan pemikiran beliau dengan karya sosial historisnya Muqaddimah yang diakui dunia. Konsep dan pemikiran Ibnu Kaldun khususnya tentang pendidikan anak masih aktual dan pantas untuk digali serta ditampilkan, seperti orientasi pendekatan ilmu kepada anak-anak melalui contoh kehidupan, pendidik harus membawakan teladan utama contoh yang baik bagi anak dan sebagainya.

Konsep dan pemikiran Ibnu Khaldun tidak dapat dipisahkan dari akar pemikiran Islamnya. Disinilah letak alasan Iqbal mengatakan bahwa seluruh semangat Muqaddimah yang merupakan manifestasi pemikiran Ibnu Khaldun,diilhami pengarangnya dari al-Qur'an sebagai sumber utama dan pertama 


\section{Konsep Kurikulum dan Metode Pendidikan Anak dan Remaja ...}

dari ajaran Islam. Dengan demikian konsep Ibnu Khaldun dapat dibaca melalui setting sosial yang mengitarinya yang diungkapkan baik secara lisan maupun tulisan sebagai sebuah kecenderungan.

Dari uraian di atas, penelitian dilakukan karena adanya suatu masalah yang membutuhkan pembahasan atau penyeleseian. Masalah dalam penelitian berarti juga fokus yang menjadi pusat pembahasan. Secara umum masalah adalah suatu keadaan yang bersumber dari dua faktor atau lebih yang menghasilkan situasi yang membingungkan (Lexy J Moleong, 1993: 62). Dalam penelitian ini masalah ini terfokus pada Bagaimana konsep Kurikulum dan Metode pendidikan Anak dan Remaja menurut Ibnu Khaldun dan relevansinya terhadap proses pendidikan saat ini

Mengingat obyek penelitian dalam tulisan ini adalah kitab, sedangkan kitab tersebut masuk dalam kategori kepustakaan, maka jenis penelitiannya peneliti masukkan dalam "research kepustakaan" (Sutrisno, 1993: 19) maksudnya peneliti mencari informasi-informasi dalam buku-buku atau kepustakaan yang ada kaitannya dengan penelitian ini.

Metode yang digunakan dalam penelitian data adalah penelitian kepustakaan (library research) dengan membaca karyakarya Ibnu Khaldun sebagai data primer yaitu kitab Muqaddimah Ibnu Khaldun dan kitab-kitab pendukung yaitu di antaranya kitab al-Ta'rif Ibnu Khaldun wa Rihlatuhu Ghorban wa syirqon dan kitab al- Ibar, dan buku-buku komentar terhadap pemikiran pendidikan Ibnu Khaldun sebagai data sekunder seperti buku karya Fathiyah Hasan Sulaiman yang berjudul Ibnu Khaldun tentang Pendidikan dan buku karangan Fuad Bali dan Wardi yang berjudul Ibnu Khaldun dan Pola Pemikiran Islam.

Dalam menganalisis data, digunakan metode analisis isi (content analyzing). Metode ini dimaksudkan untuk menganalisis makna yang terkandung dalam konsep pendidikan Ibnu Khaldun. Isi yang terkandung dalam penelitian ini kemudian dikelompokkan melalui tahap identifikasi, klasifikasi, dan kategorisasi, kemudian dilanjutkan dengan interpretasi (Cik Hasan, 2002: 8).

Dalam menganalisis data yang terkumpul digunakan metode komparatif, hal ini digunakan untuk memperoleh kesimpulan dengan menilai faktor-faktor tertentu yang berhubungan dengan 
situasi yang diselidiki dan membandingkan dengan faktor-faktor lain (Winarno S, 1972). Sehingga diharapkan dapat menemukan aktualisasi, relevansi dan kemungkinan pengembangannya yang hadir sebagai solusi alternative (Noeng Muhadjir, 1989: 99).

\section{B. Pembahasan}

\section{Biografi Ibnu Khaldun}

Nama lengkap Ibnu Khaldun yaitu Abdu al-Rahman Ibn Muhammad Ibn Muhammad Ibn Muhammad Ibn al-hasan bin Jabiribn Muhammad Ibn Ibrahim Ibn Khalid Ibn Utsman Ibn Hani Ibn Khattab Ibn Kuraib ibn Ma'dikarib Ibn al-Harits Ibn Wail Ibn Hujar atau lebih dikenal dengan sebutan Abdur Rahman Abu Zayd Muhammad Ibn Khaldun.

Abu Zaid Abdul Rahman Ibnu Khaldun dilahirkan di Tunisia pada tanggal 1 Ramadhan $734 \mathrm{H}$, bertepatan dengan tanggal 27 Mei 1332 M. Keluarganya berasal dari Hadramaut, sebuah daerah pertanian yang cukup subur di kawasan Jazirah Arab sebelah selatan. Mereka dating di Spanyol pada masa pemulaan pendudukan Islam di sana (B. Lewis, et.al, 1971: 825). Nenek moyangnya berasal dari Hadramaut yang kemudian berimigrasi ke Seville pada abad ke VIII setelah semenanjung itu dikuasai Arab Muslim (Ahmad, 1996: 11).

Nenek moyang Ibnu Khaldun berasal dari salah satu suku yang ada di daerah Arab sebelah selatan tepatnya di wilayah Yaman. Ibnu Khaldun adalah cucu keempat dari keturunan Khaldun, yang juga menjadi nama sukunya, nama aslinya Khaldun adalah Khalid, beliau dikenal dengan nama Khaldun karena sesuai dengan kebiasaan orang-orang Andalusia dan orang-orang Maghribi yang menambahkan huruf wawu dan nun di belakang nama-nama orang terkemuka sebagai tanda penghormatan dan pengagungan, seperti Hamid menjadi Hamdun, Zaid menjadi Zaidun dan Khalid menjadi Khaldun (Ali Abd al Wahid, 1985: 4).

Pada abad ke VIII M nenek moyang Ibnu Khaldun merantau ke Spanyol karena tertarik dengan adanya kemenangan dan penaklukan Islam di sana. Ia menetap di Comona, sebuah kota kecil yang berada di tengah-tengah antara tiga segi yaitu Cordova, Sevilla, dan Granada (Osman Raliby, 1998: 13). 


\section{Konsep Kurikulum dan Metode Pendidikan Anak dan Remaja ...}

Kedaulatan atas kota itu menurut sebutan memang terletak di atas tangan seorang raja, akan tetapi kekuatan dan kekuasaan, sebenafrnya atas segala persoalan dipegang dan dijalankan oleh keluarga-keluarga elit. Mereka berdiam di istana-istana yang serba indah dan puri-puri yang megah(Osman Raliby, 1998: 15).

Perebutan kembali Spanyol oleh umat Kristen memaksa umat Islam melintasi selat Jibaltar menuju ke Afrika pada tahun 1248 M. Tidak begitu lama kemudian Sevilla dirampas kembali oleh Ferdinand III dari Leon dan Gastilla. Keluatga Ibnu Khaldun mengambil keputusan yang bijaksana, mereka menyadari akan akibat buruk yang mungkin terjadi menimpa mereka. Untuk sementara waktu mereka pindah ke Centau dimana pada waktu itu gubernurnya adalah orang dari Hafs. Gubernur tersebut menerima mereka dengan tangan terbuka. Kepala keluarga mereka pada waktu itu adalah al-Hasan Ibn Muhammad Ibn Khaldun, kakek ke empat dari pengarang kitab Muqaddimah (A. Mukti Ali, 1970: 15). Selanjutnya tidak berapa di Centa, al-Hasan pergi Ke Mekah untuk menunaikan ibadah haji. Setelah kembali dari Mekah ia menetap di Bougie sebagai pegawai tinggi dari Kerajaan Hafsah (Osman Raliby, 1998: 16).

Tempat tinggal mereka sebagian besar di Tunisia. Pada waktu amirnya bernama Abu Zakaria. Dari beliaulah al-Hasan memperoleh bantuan dan perlindungan. Setelah Abu Zakaria meninggal dunia kemudian digantikan anaknya yang bernama Yahya, kemudian saudaranya yang bernama Abu Ishak, selama itu pula Bani Khaldun dapat menikmati kekuasaan dan kekayaan (A. Mukti Ali, 1970).

Setelah al-Hasan meninggal dunia maka anak-anaknya yang bernama Abu Bakar Muhammad (ayah dari kakek Ibn Khaldun) yang juga sarjana dalam ilmu politik menjadi mentri keuangan dari dinasti Hafsiah (Osman Raliby, 1998: 16). Kemudian dia menjauhkan diri dari soal-soal kenegaraan meskipun sebenarnya masih besar pengaruhnya dan mengganti kesibuknnya dengan mempelajari ilmuilmu keagamaan. Beliau meninggal dunia pada tahun $737 \mathrm{H}$ atau $1337 \mathrm{M}$.

\section{Dasar dan Tujuan Pendidikan Menurut Ibnu Khaldun}


Menurut Ibnu Khaldun bahwa ilmu pendidikan bukanlah suatu aktifitas yang semata-mata bersifat pemikiran dan perenungan, serta jauh dari aspek-aspek pragmatis di dalam kehidupan, tetapi ilmu pengetahuan (pendidikan) tidak lain adalah dua buah fenomena sosial, termasuk fenomena sosial yang menjadi ciri masyarakat manusia (Fathiyah, 1991: 33). Kehidupan dan semua aktifitas yang merupakan fenomena sosial dari masyarakat haruslah mempunyai dasar. Dasar pendidikan anak menurut Ibnu Khaldun tidak lepas dari dasar pendidikan Islam. Pendidikan Islam itu didasarkan pada kaedah hukum dalam al-Qur'an dan alHadits.Athiyah al-Abrasyi menandaskan bahwa dasar pendidikan Islam adalah al-Qur'an dan al-Hadits, yaitu bahwa pendidikan Islam dibangun atau didasarmkan atas kaidah hukum yang ditulis dalam al-Qur'an dan atas sabda Rasulullah (Athiyah al-Abrasyi, tt: 284).

Dasar pendidikan anak menurut Ibnu Khaldun adalah alQur'an yakni dalam menemukan gagasan-gagasan di bidang pendidikan anak, karena al-Qur'an memberikan pandangan yang mengacu pada kehidupan di dunia dan asas-asas dasarnya memberi petunjuk kepada pendidikan Islam (Abdurrahman, 1994: 20) (Abdurrahman, 1994: 20).

Dalam meneliti fenomena yang ada di dalam masyarakat Ibnu Khaldun menggunakan metode ilmiah yaitu dengan cara observasi dan berpikir secara logika, sehingga dengan penelitiannya memunculkan penemuan tentang teori hubungan sebab akibat atau disebut sunnatullah dan menciptakan teori-teori dan konsep-konsep baru dalam pendidikan remaja.

Al-Qur'an sebagai rujukan dan acuan pendidikan anak maka muncullah gagasan baru dalam pendidikan anak yang sesuai dengan kondisi dan situasi yang ada di dalam masyarakat, melalui pengamatan dan kajian secara empiris yang dilakukan oleh Ibnu Khaldun di negara-negara Islam yang ada di Afrika dan Andalusia.

Ibnu Khaldun sendiri menyebutkannya dalam kitab Muqaddimahnya yang berbunyi "Bahwa sesungguhnya mengajar alQur'an kepada anak termasuk remaja itu merupakan syiar agama atau symbol agama. Ahli agama mengambil dan memasukannya dalam semua masa-masa mereka. Hal itu akan mengilhami hati dengan menancap dan masuknya iman dan akidahnya dari ayat-ayat 


\section{Konsep Kurikulum dan Metode Pendidikan Anak dan Remaja ...}

al-Qur'an dan sebagian dari matan hadits dan al-Qur'an menjadi dasar pengajaran dan fondasi semua keahlian yang diperoleh kemudian (Ibnu Khaldun, tt: 537-538).

Meskipun dalam pernyataan Ibnu Khaldun tidak disebutkan secara jelas, namun sudah tersirat di dalamnya bahswa al-Qur'an menjadi dasar dari ta'lim (pengajaran). Karena al-Qur'an dan al-Hadits merupakan dasar agama, maka Ibnu Khaldun juga mengisyaraktkan kembali pada pentingnya penghafalan pada alQur'an.

Ibnu Khaldun mengatakan dalam Muqaddimahnya: "Ibnu Khaldun mengisyaratkan pada pentingnya penghafalan al-Qur'an bagi anak-anak, beliau menjelaskan bahwa pengajaran al-Qur'an dalam semua system pengajaran pada berbagai negara-negara Islam, karena al-Qur'an merupakan syiar agama yang dapat mendatangkan pada kuatnya iman" (Athiyah al-Abrasyi, tt: 165).

Dari pendapat dan pernyataan Ibnu Khaldun di atas dapat ditarik kesimpulan bahwasannya al-Qur'an merupakan dasar pendidikan yang juga merupakan dasar pendidikan remaja. Adapun tujuan pendidikan anak menurut konsep Ibnu Khaldun juga tidak disebutkan secara langsung, tetapi dapat diungkapkan bahwa sesungguhnya tujuan pendidikan yang bersumberkan al-Qur'an adalah untuk mencapai tujuan pembentukan akidah atau keimanan yang mendalam pada diri remaja dan menumbuhkan dasar-dasar mulia jalan agama yang diturunkan untuk mendidik jiwa manusia serta menegakkan moral dan akhlak yang membangkitkan pada perbuatan baik, (Ali al-Jumbulati, 1994: 58) dan itu merupakan tujuan yang paling pokok dan terpenting dalam pendidikan remaja.

Hal yang demikian dikatakan Ibnu Khaldun dengan tegas dalam kitabnya Muqaddimah: "Bahwa sesungguhnya tujuan dari hal itu adalah menanmkan remaja dan memasukkan akidah keimanan dalam dirinya, dan menanamkan dasar-dasar akhlak yang mulia dari jalan agama yang membersihkan pada jiwa, yang menegakkan akhlak dan membangkitkan kebaikan" (Athiyah al-Abrasyi, tt: 258).

Pernyataan di atas didukung oleh sebagian tokoh

pendidikan misal alp-Qabisi, Ibnu Sina dan juga al-Ghazali, yang menyebutkan bahwa sebagian dari mereka ada yang menanamkan dengan pendidikan moral dan akhlak atau menganjurkan rasa 
keagamaan atau menetapkan kaidah yang tertentu (thiyah alAbrasyi, tt: 30).

Dari pernyataan di atas dapat ditarik kesimpulan bahwa tujuan pendidikan remaja menurut Ibnu Khaldun adalah penanaman akidah / keimanan dan akhlak yang mulia pada diri anak. Hal ini berarti bahwa anak lebih ditekankan pada tujuan ilmu agama, kemampuan agama dan akhlak yang baik dalam memberikan pengaruh yang besar untuk perkembangan anak sampai usia dewasa. Hal ini tersirat dalam pernyataan Ibnu Khaldun dalam kitabnya Muqaddimah di atas tadi.

Pendidikan agama dan pendidikan akhlak (budi pekerti) tidak ditumbuhkan kecuali sejak kecil atau usia dini, khususnya melalui kehidupan keagamaan yang saleh dan utama yang dihayati oleh keluarga itu yang dilakukan oleh anak di rumah, sekolah dan dalam masyarakat (Fathiyah, 1991: 73). Jadi apabila dianalisa secara mendalam bahwa tujuan pendidikan anak menurut konsep Ibnu Khaldun adalah membentuk anak agar menjadi orang dewasa yang berkepribadian baik, berbudi luhur, berakhlak mulia melalui nilai pendidikan dalam al-Qur'an.

Konsep Ibnu Khaldun sesuai dengan konsep pendidikan Ibnu Sina yang menyatakan bahwa pendidikan akhlak (budi pekerti) ini merupakan tujuan utama dari pendidikan pada umumnya, sebab tujuan pendidikan itu adalah membentuk orang yang berakhlak mulia disamping membentuk kepribadian yang kuat di kalangan anak-anak.

Membentuk kepribadian remaja yang mempunyai akhlak mulia itu merupakan tujuan pokok, utama dan inti dari tujuan pendidikan remaja menurut konsep Ibnu Khaldun, namun ketika anak sudah menginjak remaja dan dewasa maka tujuan pendidikan anak harus ditambah dengan tujuan hidup remaja yaitu dia harus mempunyai alat atau keahlian yang dipelajari dari berbagai ilmu pengetahuan untuk dia di masa mendatang dalam arti untuk giat beraktifitas dan bekerja dalam mencukupi kehidupannya dan keluarganya.

Maka dapatlah dianalisa dengan menyimpulkan bahwa tujuan menurut konsep Ibnu Khaldun ketika remaja menginjak dewasa yaitu memberikan kesempatan kepada pikiran untuk aktif 


\section{Konsep Kurikulum dan Metode Pendidikan Anak dan Remaja ...}

dan bekerja, karena aktifitas ini sangat penting bagi terbuka pikiran dan kematangan anak kemudian kematangan ini dapat memberikan manfaat pada masyarakat, memperoleh berbagai ilmu pengetahuan sebagai alat untuk membantunya hidup dengan baik di dalam masyarakat maju dan berbudaya, dan memperoleh lapangan pekerjaan yang digunakan untuk memperoleh rizki.

\section{Kurikulum Pendidikan Anak dan Remaja Menurut Ibnu Khaldun}

Salah satu komponen operasional pendidikan sebagai suatu system adalah merupakan bahan-bahan atau materi pelajaran apa saja yang harus disajikan dalam proses belajar mengajar. Kurikulum adalah merupakan landasan yang digunakan pendidik untuk membimbing peserta didiknya kea rah tujuan pendidikan yang diinginkan melalui akumulasi sejumlah pengetahuan, ketrampilan dan sikap mental.

Konsep Ibnu Khaldun tentang konsep kurikulum pendidikan dapat dilihat dari konsep epistemologinya. Menurut beliau bahwa ilmu pengetahuan dalam kebudayaan umat Islam dapat dibagi kepada dua bagian, yaitu :

a. Ilmu pengetahuan syar'iyyah yang berkenaan dengan hokum dan ajaran agama Islam. Ilmu pengetahuan syari'iyyah yaitu ilmuilmu yang bersandar pada otoritatif syar'I (Tuhan / Rasul) dan akal manusia tidak mempunyai peluang untuk "mengotakatiknya" kecuali dalam lingkup cabang-cabangnya, itupun masih harus berada dalam kerangka diktum dasar otoritatif tersebut. Ilmu ini diantaranya adalah tentang al-Qur'an, Hadits, prinsipprinsip Syari'ah, fiqh, teologi dan sufisme.

b. Ilmu pengetahuan filosofis yaitu ilmu yang bersifat alami yang diperoleh manusia dengan kemampuan akal dan pikirannya. Lingkup persoalan, prinsip-prinsip dasar dan metode pengembangannya sepenuhnya berdasar daya jangkau akal pikir manusia.

Ilmu pengetahuan filosofis meliputi: 1. Ilmu Mantik (logika) yakni ilmu yang menjaga proses penalaran dari hal-hal yang sudah diketahui agar tidak mengalami kesalahan, 2. Ilmu Pengetahuan Alam, yakni ilmu tentang realitas empiris, indra baik berupa unsureunsur atomik, bahan-bahan tambang, benda-benda angkasa, maupun 
gerak alam jiwa manusia yang menimbulkan gerak dan sebagainya. 3 . Ilmu Metafisika yakni hasil pemikiran tentang hal-hal metafisis. 4. Ilmu Matematika. Ilmu ini meliputi empat disiplin keilmuan yang disebut al-ta'lim yakni a) ilmu ukur (alhandasah), b).Ilmu Aritmatika c. ilmu musik, dan d) astronomi. Ilmu pengetahuan filosofis juga sering disebut sains alamiah. Hal ini disebabkan karena dengan potensi akalnya setiap orang memiliki kemampuan untuk menguasainya dengan baik.

Ilmu pengetahuan syar'iyyah dan filsofis merupakan pengetahuan yang ditekuni manusia (anak didik) dan saling berinteraksi baik dalam proses memperoleh atau proses mengajarkannya. Konsepsi ini kemudian merupakan pilar dalam merekonstuksi kurikulum pendidikan Islam yang ideal, yaitu kurikulum pendidikan yang mampu mengantarkan peserta didik yang memiliki kemampuan membentuk dan membangun peradaban umat manusia.

Ibnu Khaldun mengakhirkan materi al-Qur'an yang diajarkan kepada anak-anak merupakan metode pendekatan dalam pendidikan anak yang dianggap baik oleh beliau yang bersifat psikologis. Pengajaran al-Qur'an kepada anak harus diakhirkan setelah mengajarkan bahasa arab dan berhitung, meskipun kebiasaan yang umum pada saat itu tidak menyetujuinya dengan hal itu dan ada bahaya lainnya yaitu kemungkinan anak mudah tergoda untuk mengabaikan pengajaran al-Qur'an.

Maka jelaslah perlu dijernihkan bahwa mengajarkan alQur'an pada anak itu perlu untuk didahulukan, meskipun anak belum memahami betul tentang arti dan makna ayat-ayat al-Qur'an, mengingat pentingnya pengajaran al-Qur'an untuk menanamkan keimanan anak dan membiasakan membaca serta menghafal alQur'an dengan baik dan benar.

Sedangkan kurikulum pendidikan remaja secara keseluruhan adalah sebagai berikut: a. al-Qur'an, b. al-Hadits, c. Bahasa Arab, d. Syi'ir (sastra), e. Kisah-kisah yang baik atau sejarah, f. Akhlak / budi pekerti, g. Ilmu hitung. Al-Qur'an dan al-hadits ini termasuk ilmuilmu naqli yaitu ilmu yang dipindahkan dari orang yang mengemukakannya atau menciptakan dan saling diwarisi oleh para generasi (Fathiyah Hasan, 1991: 43). 


\section{Konsep Kurikulum dan Metode Pendidikan Anak dan Remaja ...}

Bahasa Arab adalah ilmu-ilmu alat yang membantu ilmuilmu agama dan termasuk ilmu aqli, sedangkah kisah-kisah syi'ir juga termasuk ilmu aqli yang berisi pujian bagi orang-orang yang baik dan celaan terhadap orang-orang yang buruk. Ilmu berhitung atau ilmu handasah termasuk juga ilmu aqli yang menitik beratkan pada ukuran-ukuran yang mencakup ilmu-ilmu tentang angka (Fathiyah, 1991: 50-51).

Dapat dikatakan bahwa al-Qur'an danm al-hadits adalah ilmu-ilmu yang mengandung tujuan dari ilmu itu sendiri atau dzat ilmu (Ali al Jumbulati, 1994: 231). Sedangkan bahasa Arab, berhitung atau ilmu hisab yang untuk kepentingan ilmu syari'ah maka termasuk ilmu-ilmu yang mengandung tujuan pada ilmu itu sendiri atau dzatnya.

Syi'ir yang termasuk sastra hyang memuat kisah-kisah zaman terdahulu. Ungkapan-ungkapan yang baik yang diajarkan kepada anak pemula atau anak usia dini yang mengandung pelajaran moral / akhlak adalah hal yang harus diajarkan pada anak karena dengan mengenal sya'ir-sya'ir maka anak akan mengetahui sejarah orang terdahulu dan dijadikan contoh dan suri tauladan. Hal ini tentunya lewat syi'ir-syi'ir yang berbahasa Arab, karena dengan mengajarkan syi'ir maka anak akan mendapat nukilan atau cuplikan teks terdiri dari tata bahasa Arab, disampig sebagai contoh atau pelajaran yang dapat diambil pelajaran dan dapat dipraktekkan.

Sebelum membahas konsep Ibnu Khaldun mengenai materi pendidikan yang dikembangkan melalui kurikulum, perlu kiranya di sini diberikan pengertian kurikulum secara jelas lagi. Kurikulum pada zaman Ibnu Khaldun itu berbeda dengan pengertian kurikulum pada masa sekarang. Pada zaman Ibnu Khaldun kurikulum itu masih sempit pengertiannya yaitu masih terbatas pada maklumatmaklumat dan pengetahuan yang dikemukakan oleh guru atau madrasah dalam bentuk mata pelajaran yang terbatas dalam bentukbentuk kitab-kitab madrasah tradisional tertentu dan berbagai buku peninggalan lama yang dikaji oleh anak didik dalam tiap tahapan pendidikan (Omar Moh. At-Thoumy, , 1992: 480).

Ibnu Khaldun mencoba untuk membandingkan kurikulum yang berlaku pada masanya yaitu kurikulum pada tingkat rendah yang terjadi di negara-negara Islam bagian barat dan bagian timur 
dan dapat dianggap pembicaraan ini sesuai dengan kejadian yang sebenarnya. Ibnu Khaldun bukan hanya menceritakan keadaan pendidikan pada masa XIV M, tetapi juga keadaan pendidikan pada masa sebelumnya, namun akhirnya Ibnu Khaldun memilih cara yang dipakai oleh pendidikan Andalusia (Barat) dan cara yang dikemukakan oleh Qadli Abu Bakar Ibnu Araby yang dianggapnya sangat baik (Ibnu Khaldun, tt: 539).

Adapun penduduk Andalusia mereka mengajarkan al-Qur'an dan kitab juga dalam pengajaran, tetapi mengingat bahwa al-Qur'an merupakan dasar pengajaran dan asasnya serta sumber agama dan ilmu, maka mereka menjadikan al-Qur'an sebagai dasar pengajaran, sehingga dengan hal itu mereka tidak meringkas dengan al-Qur'an saja namun mencampurnya dengan riwayat syi'ir, surat menyurat dan memberikan kaedah bahasa Arab dan menghafalnya, juga pelajaran tajwid, khot (penulisan arab dengan tulisan bagus) dan kitab. Pemeliharaan mereka dalam mengajar dengan khot baik itu tidak tertentu dibanding dengan pemeliharaan anak itu ketika sudah keluar dari umur balighnya atau bahkan sampai remaja dan dewasa dan sudah mendalami sebagian dari bahasa Arab dan syi'ir (Ibnu Khaldun, tt: 539).

Ibnu Khaldun sendiri setuju dengan pendapat yang diungkapkan oleh Qadli Abu Bakar dan kurikulum yang dipakai dan digunakan oleh penduduk Andalusia yang mengkombinasikan pengajaran al-Qur'an dengan ilmu-ilmu yang lain dan lebih menekankan atau menitik beratkan pada mempelajari bahasa Arab sehingga anak mempunyai harapan untuk menguasai bahasa Arab.

Inilah konsep Ibnu Khaldun mengenai kurikulum pendidikan anak yang lebih menekankan pada pengajaran al-Qur'an dan bahasa Arab, beliau juga menempatkan sejajar antara ilmu naqliyah dan ilmu aqliyah, dan suatu hal yang sangat penting yaitu apa yang dianjurkan oleh beliau bahwa dalam meletakkan kurikulum hendaknya diperhatikan pentingnya pengajaran dasar bahasa Arab dalam seluruh asas belajar karena dengan penguasaan bahasa yang lebih baik anak akan lebih mudah dan lancar dalam mempelajari ilmu pengetahuan yang lain.

\section{Metode Pendidikan Anak dan Remaja Menurut Ibnu Khaldun}




\section{Konsep Kurikulum dan Metode Pendidikan Anak dan Remaja ...}

Dalam rangka mencapai tujuan pendidikan, metode memegang peranan penting. Penggunaan metode yang sesuai dengan bahan pelajaran yang diajarkan, anak murid yang diajar, lingkuangan tempat mengajar, akan membawa suasana proses belajar-mengajar berjalan mulus dan efektif. Metode pendidikan adalah segala segi kegiatan yang terarah yang dikerjakan oleh guru dalam rangka kemestian-kemestian mata pelajaran yang diajarkannya. Ciri-ciri perkembangan peserta didik dan suasana alam di sekitarnya dan tujuan membimbing peserta didik untuk mencapai proses belajar yang diinginkan dan perubahan yang dikehendaki pada tingkah laku mereka.

Dalam membahas metode pendidikan anak, penulis memaparkan konsep Ibnu Khaldun mengenai metode pengajaran yang merupakan bagian terbesar yang beliau bahas dalam kitab Muqaddimahnya. Dalam sejarah pendidikan Islam dapat diketahui bahwa para pendidik muslim dalam berbagai kondisi dan situasi yang berbeda telah menerapkan berbagai macam metode mengajar bagi para pendidik, melainkan juga metode belajar hyang harus digunakan oleh peserta didik.

Ibnu Khaldun mengkritik metode mengajar yang digunakan pendidikan pada umumnya, pemikiran mereka (pendidik) sebagian besar kurang tahu dan memahami cara dan metode mengajar yang baik dan efektif, mereka hanya menyampaikan dan menjelaskan materi pelajaran tanpa mengetahui kesiapan dan kemampuan anak sehingga pelajaran yang mudah akan menjadi sulit sebab kurang baiknya metode pengajarannya (Ibnu Khaldun, tt: 534).

Dalam hal ini Ibnu Khaldun sebagai pendidik yang berkemampuan mengajar berpendapat bahwa pemberdayaan metode yang dapat digunakan untuk menyampaikan pengetahuan kepada anak bergantung pada sejauh mana kematangan persiapan pendidik dalam mempelajari hidup kewajiban anak-anak didiknya, sehingga diketahui sejauh mana kematangan kesiapan mereka dan bakat-bakat ilmiahnya (Ali al-Jumbulati, 1994: 196).

Ibnu Khaldun menentang metode verbalisme dalam pengajaran dan menghinari dari hafalan yang tidak memahami sesuatu yang dapat dibuktikan melalui panca indra materi yang dihafalkan anak. Karena menghafal dengan cara demikian ini akan 
meghambat kemampuan memahami, beliau menghimbau agar pendidik menggunakan metode ilmiah dengan menumbuhkan kemampuan melalui kekuatan berbicara dan memahami serta diskusi (Ali al-Jumbulati, 1994: 197).

Beliau juga mengkritik pengajaran yang digunakan di negara Maghrib yang pendidikannya membutuhkan waktu cukup lama yaitu 16 tahun, tetapi belum berhasil secara penuh dan maksimal karena pemeliharaan pengajarannya mereka dengan metode hafalan saja. Hal ini berbeda dengan sistem pengajaran di madrasah Tunisia, proses pendidikannya tdak membutuhkan waktu yang lama yaitu tidak melebihi 5 tahun, pendidikannya berhasil karena perhatian pendidik dengan pemahaman dan diskusi dan anak diajak berpikir serta memperhatikan kesiapan dan kematangan remaja (Athiyah al-Abrasyi, tt: 289-290).

Metode mengajar dan gaya mengajar yang harus dijaga dan dipelihara serta dipertahankan oleh pendidik adalah mengajar anak didik dengan metode pentahapan dan pengulangan atau metode tadarruj wa tikrar. Menurut Ibnu Khaldun mengajar anak-anak hendaknya didasarkan pada prinsip-prinsip pandangan bahswa tahap permulaan pengetahuan adalah bersifat total atau menyeluruh, kemudian bertahap, baru terperinci, sehingga anak dapat mudah menerima dan memahami permasalahan pada tiap bagian dari ilmu yang diajarkan (Ali al-Jumbulati, 1994:199).

Hal tersebut dijelaskan Ibnu Khaldun di dalam kitab Muqaddimahnya bahwa mengajarkan ilmu pengetahuan kepada anak didik yang belajar itu melalui metode pentahapan, sedikit demi sedikit, dalam arti bahwa sesungguhnya mengajari ilmu pengetahuan kepada para murid itu yang berfaedah, jika pengajaran itu dilaksanakan atas metode pentahapan, sedikit demi sedikit, pertama kali yang diajarkan adalah masalah dari setiap bab dari suatu cabang ilmu yang merupakan pokok dari bab kitu dan dijelaskan secara keseluruhan dan juga harus dijaga atas kekuatan akal pikirannya dan persiapannya untuk meneriman sesuatu yang datang sehingga sampai akhir dari ilmu itu (Ibnu Khaldun, tt: 533).

Jadi konsep Ibnu Khaldun mengenai mengajarkan materi pelajaran dengan metode pentahapan, maka ada 3 tahapan untuk dilewati, yaitu sebagai berikut: 


\section{Konsep Kurikulum dan Metode Pendidikan Anak dan Remaja ...}

1. Tahap ini dinamakan tahap permulaan. Dalam gtahap ini ilmu pengetahuan yang diberikan secara sederhana belum terurai.

2. Pada tahap ini guru mengulang kembali pelajaran dari bab pertama, pelajaran lebih ditingkatkan, uraian diperluas dan diperinci.

3. Tahap akhir ini guru mengulang materi pelajaran dari awal sampai akhir.

Konsep metode pentahapan secara bertingkat ini menurut pendapat beliau sangat besar faedah dan manfaatnya dalam upaya menjelaskan dan menetapkan ilmu dalam pikiran dan jidwa anak serta memperkuat kemampuan mental dan jiwanya untuk lebih memahami ilmu. Alasan mengulang-ulang sampai beberapa kali (tiga kali) adalah karena kesiapan memahami ilmu pengaetahuan berlangsung secara bertahap.

Inilah metode umum yang diterangkan oleh Ibnu Khaldun , beliau mengatakan bahwa metode ini adalah metode yang baru karena sesuai dengan sistem belajar bertahap. Metode ini berdasarkan penjelasan pendidikan pelajaran dan penyajiannya kepada anak secara sederhana sampai kepada yang rumit (Fathiyah Hasan Sulaiman, 1991: 80).

Disamping itu Ibnu Khaldun menyarankan agar pendidik atau guru dalam mengajar anak dapat membawa contoh-contoh berupa benda yang dapat diraba dalam arti memakai alat atau media pengajaran. Dalam hal ini Ibnu Khaldun tampaknya memberikan pedoman kepada para pendidik hendaknya mempergunakan alat peraba untuk mengajarkan anak.

Ibnu Khaldun dalam kitabnya mengatakan bahwa anak-anak yang mempunyai daya serap atau daya tanggap yang lemah dan kurang hendaknya ditarik dan dipermudah dengan sesuatu benda yang nyata (Nashruddin Thoha, 1979: 97).

Ibnu Khaldun mendorong kepada penggunaan alat-alat peraga, karena anak pada waktu mulai belajar permulaannya lemah dalam memahami pelajaran dan kurang daya pengamatannya. Alatalat peraga itu membantu kemajuan ilmu pengetahuan yang diajarkan kepadanya dan hal inilah yang ditekankan beliau, karena memang anak panca indranya dalam proses penyusunan pengalamannya (Ali al-Jumbulati, 1994: 210). 
Ibnu Khaldun menyarankan agar pelajaran harus dimulai dengan metode umum. Dalam mengajar juga pelajaran harus dimulai dengan contoh-contoh dan misal-misal yang lengkap, sesudah melalui soal jawab dan memilih contoh, baru anak-anak diantarkan kepada kaedah atau tujuan atau jug disebut kesimpulan (Nashruddin Thoha, 1979: 98) .

Pendapat lain Ibnu Khaldun tentang metode pendidikan anak yaitu antara jam pelajaran pertama dengan jam pelajaran kedua jangan terlalu lama. Hal yang demikiam itu diungkapkan Ibnu Khaldun dalam kitab Muqaddimahnya, yaitu "Begitu juga yang dianjurkan oleh Ibnu Khaldun yaitu tidak boleh memperpanjang atau melamakan bagi anak didik atas atas pelajaran yang satu dengan memisahkan majlis atau memutus atau memotong pelajaran satu dengan yang lainnya, karena hal itu akan mendorong atau menyebabkan pada kelupaan atau putusnya masalah-masalah pelajaran setengahnya dengan setengahnya maka sulit menghasilkan ketrampilan atau kecakapan. Jika pada awal ilmu dan akhirnya terjadi berpikir, maka ketrampilan dan keahlian lebih mudah hasilnya dan lebih kukuh hubungannya, karena keahliankeahlian itu hanya dihasilkan dengan kesinambungan pekerjaan dan berulangkalinya, jika akal pikiran itu dilupakan maka keahlian yang tumbuh akan dilupakan" (Ibnu Khaldun, tt: 534).

Pendapat Ibnu Khaldun tentang adanya kesinambungan atau adanya hubungan antara pertemuan pertama dengan pertemuan berikutnya dan seterusnya yang terlalu lama, namun di dalam hal ini perlu dan penting diperhatikan tentang adanya jam istirahat. Dengan adanya jam istirahat maka antara beberapa pelajaran itu dapat mengantarkan anak didik pada ketrampilan dan pengetahuan yang melekat dalam jiwanya (Athiyah al-Abrasyi, $t$ : 294). Metode lain yang digunakan dalam mendidik anak adalah metode pemberian hukuman (punishmaent) atau sanksi. Ibnu Khaldun menganjurkan ketika guru mengajar pada anak didik dengan kasih sayang dan memperlakukan anak dengan lemah lembut dan halus, tidak dengan kekerasan karena hal itu akan membahayakan pada akhlak dan prilaku anak dan cenderung malas serta tidak giat. Maka dari itu anak haruslah dididik dengan segala bentuk lemah lembut dan 


\section{Konsep Kurikulum dan Metode Pendidikan Anak dan Remaja ...}

dengan mendekati mereka yaitu dengan pendekatan yang manusiawi, dan pendidik harus dapat menghampiri jiwa mereka.

Ibnu Khaldun sendiri mengatakan dalam Muqaddimahnya yaitu sebagai berikut: "Bahwa sesungguhnya pemberian hukuman dalam pelajaran itu akan membahayakan jiwa anak, apalagi bagi anak-anak yang masih kecil, karena hal itu termasuk tindakan yang buruk, apabila pendidik itu bertindak kasar dan bersifat keras pada anak-anak atau pemnbantu anak maka anak akan sempit jiwanya dan mengajak pada kemalasan dan mendorong pada kedustaan dan kejelekan" (Ibnu Khaldun, tt: 540 ).

Maka dari sini dapat dikatakan bahwa metode hukuman yang dilaksanakan untuk mengajar anak, seharusnya hukuman itu sendiri oleh pendidik yang akan mengakibatkan anak cenderung pasif. Namun hukuman tersebut dapat dilaksanakan sebatas untuk mendidik anak dan sangat terpaksa agar anak cenderung segan dan simpatik.

\section{Simpulan}

Dari uraian diatas dapat ditarik kesimpulan bahwa konsep kurikuum dan metode pendidikan bagi anak dan remaja menurut pandangan Ibnu Khaldun menitik beratkan pada epistemologi keilmuanya, yaitu Al Qur'an dan Al Hadist sebagai Sumber utama ajaran Islam. Pendidikan akhlak bagi remaja dan menumbuhkan dasar-dasar keutamaan dalam jiwa anak. Anak menurut pandangan Ibnu Khaldun itu dipengaruhi dengan hal ikut-ikutan dan meniru serta contoh-contoh yang baik yang mereka lihat dari pada dipengaruhi melalui nasehat dan petunjuk. Didalam praktek pendidikan dan pengajaran, metode ini dilaksanakan dalam dua cara, yaitu secara langsung dan tidak langsung. Secara langsung bahwa guru harus sebagai contoh dan teladan bagi anaknya, secara tidak langsung yaitu mengajarkan anak kisah-kisah dan cerita yang baik yang diambil uswatun hasanahnya.

Menurut konsep Ibnu Khaldun bahwa harus ada hubungan yang kuat dan erat antara anak dan pendidik, baik itu dilaksanakan di dalam kelas maupun di luar kelas, hubungan guru dengan anak sama juga dengan hubungan bapak dan remaja. Jadi ketika hubungan antara pendidik dan anak atau anak didik itu terjalin 
Ahmad Falah

erat, maka kesempatan luas bagi anak untuk meniru dan duduk bersama guru-guru mereka dari dekat dan berhubungan dan mengambil manfaat dan akhlaknya dan dapat memindahkan ilmu dan pendapatnya dan mencobanya dalam kehidupan. Dengan demikian, adanya hubungan yang erat terjalinlah hubungan antara guru dan anak remaja dan memberikan manfaat yang besar dalam pengajaran. 


\section{Konsep Kurikulum dan Metode Pendidikan Anak dan Remaja ...}

\section{DAFTAR PUSTAKA}

A. Mukti Ali, Ibnu Khaldun dan Asal-Usul Sosiologi, Yogyakarta: Yayasan Nida, 1970, h. 15

Abdullah Nashih Ulwan, Pendidikan Anak Menurut Islam Pemeliharaan Kesehatan Jiwa Anak, terj. Khalilullah Ahmas Masjkur Hakim, Bandung: Remaja Rosdakarya, 1900, h.VII Abdurrahman saleh Abdullah, Teori-teori Pendidikan Berdasarkan alQur'an, Jakarta: Rineka Cipta, 1994, h. 20

Abu Tauhid, Beberapa Aspek Pendidikan Islam, Yogyakarta: IAIN Sunan Kalijaga Press, 1990, h. 90.

Ahmad Syafi'I Ma'arif, Ibnu Khaldun dalam Pandangan Penulis Barat dan Timur, Jakarta : Gema Insani Press, 1996, h. 11

Ali Abd al-Wahid Wafi, Ibnu Khaldun Riwayat dan Karyanya, Jakarta: Grafiti Press, 1985, h. 4.

Ali al-Jumbulati, Perbandingan Pendidikan Islam, terj. H.M. Arifin, Jakarta: Rineka Cipta, 1994, h.5

Athiyah al-Abrasyi, Ruh at-Tarbiyah wa Ta'lim, Dar-al-Ihya': Bab alHalabi, tt, h. 30

Athiyah al-Abrasyi, at-Tarbiyah al-Islamiyah wa Falasifatuha, Dar alFikr, tt, h. 289-290

B. Lewis, et. Al., The Encyclopedia of Islam, Tuta Subagide Pallos EJB, London : Inzac, 1971, h. 825

Cik Hasan Bisri dan Eva Rufaidah, Model Penelitian Agama dan Dinamika Sosial, Jakarta: Raja Grafindo Persada, 2002, h. 8

Fathiyah Hasan Sulaiman, Ibnu Khaldun Tentang Pendidikan, terj. Azra'i Zakariya, Jakarta: Minaret, 1991, h.92

Ibnu Khaldun, Muqaddimah Ibnu Khaldun, Dar al-Fikr: tt, h. 537-538

Lexy J. Moleong, Metodologi Penelitian Kualitatif Bandung : Remaja Rosda Karya, 1993, h.62

Nashruddin Thoha, Tokoh-tokoh Pendidikan Islam di Zaman Jaya Imam Ghazali dan Ibnu KHaldun, Jakarta: Mutiara, 1979, h. 97

Nashruddin Thoha, Tokoh-tokoh Pendidikan Islan dizaman Jaya Iman Ghazali dan Ibnu Khaldun, Jakarta: Mutiara, 1979, h.58

Noeng Muhadjir, Metodologi Penelitian Kualitatif, Yogyakarta: Rake Sarasin, 1989, hlm. 99

Omar Moh. At-Thoumi, Falsafah Pendidikan Islam, terj. Hasan Langgulung, Jakarta: Bulan Bintang, 1992, hlm.480 
Ahmad Falah

Osman Raliby, Ibnu Khaldun Tentang Masyarakat dan Negara, Jakarta: Bulan Bintang, h. 13.

Sutrisno Hadi, Metodologi Research, Yogyakarta: 1993, Jilid, h.19

Winarno Surachmad, Dasar dan Teknik Reseacrh, Bandung : tarsito, 1972 